\title{
A számítógépes mélytanulási technológia várható megjelenése a hazai mammográfiában
}

\author{
Ribli Dezső ${ }^{1}$ - Zsuppán Richárd ${ }^{2}$ - Pollner Péter dr. ${ }^{3}$ \\ Horváth Anna dr. ${ }^{4}$. Bánsághi Zoltán dr. ${ }^{2}$. Csabai István dr. ${ }^{1}$ \\ Bérczi Viktor dr. ${ }^{2}$. Unger Zsuzsa dr. ${ }^{2}$ \\ ${ }^{1}$ Eötvös Loránd Tudományegyetem, Komplex Rendszerek Fizikája Tanszék, Budapest \\ ${ }^{2}$ Semmelweis Egyetem, Általános Orvostudományi Kar, Radiológiai Klinika, Budapest \\ ${ }^{3}$ MTA-ELTE Statisztikus és Biológiai Fizika Kutatócsoport, Budapest \\ ${ }^{4}$ Semmelweis Egyetem, Általános Orvostudományi Kar, III. Belgyógyászati Klinika, Budapest
}

\begin{abstract}
Bevezetés és céllitüzés: A számítógépes 'mélytanulás' (deep learning) az elmúlt két évtized számítástechnikai fejlődésének legjelentősebb ajándéka. A számítógépes mélytanulásban rejlő - egyelőre még beláthatatlan - lehetőségek megértése, befogadása és alkalmazása a medicina megkerülhetetlen feladata.

Módszer: Ajándék és feladat, hiszen az exponenciálisan növekvő adatok (képalkotó vizsgálati, laboratóriumi, terápiaválasztási lehetőségek, terápia-kölcsönhatások stb.) „bitjeinek” tengerében minden vágyunk és deklarációnk ellenére mind kevésbé tudjuk a személyre és állapotra, a tumorra és környezetére szabott individuális ellátást megvalósitani. Eredmények: A jelen pillanatban felelős ellátóként - és nem kevésbé felelős finanszírozóként - azt élhetjük meg, hogy egyéni és közösségi szinten is szuboptimális folyamatokat tartunk fenn, aminek oka egyszerre az adatok bösége, ugyanakkor az ellátáshoz individuálisan fontos adatok hiánya. A számítógépes mélytanulás, a medicina lényegét adó ember-ember közti találkozás gyógyító erejét nem csorbítva - hanem inkább kiterjesztve -, ebben kínál fényt az alagútban.

Következtetés: Belátva tehát saját adatintegrációs és ismereti korlátainkat, nekünk, orvosoknak és ellátásfinanszírozóknak - sajátos elóitéleteinket és félelmeinket feladva - kell megtanulni a számítógépes mélytanulásban rejlő különleges lehetôségeket, melyek nemcsak a képalkotó diagnosztikában, hanem már napi realitásként a terápia területén is használhatók (immunterápia). A közlemény ehhez igyekszik kedvet csinálni.
\end{abstract}

Orv Hetil. 2019; 160(4): 138-143.

Kulcsszavak: gépi tanulás, mesterséges intelligencia, mammográfia, számítógép és felhasználó együttmúködése

\section{Potential applications of deep learning-based technologies in Hungarian mammography}

Introduction and aim: The technology, named 'deep learning' is the promising result of the last two decades of development in computer science. It poses an unavoidable challenge for medicine, how to understand, apply and adopt the - today not fully explored - possibilities that have become available by these new methods.

Method: It is a gift and a mission, since the exponentially growing volume of raw data (from imaging, laboratory, therapy diagnostics or therapy interactions, etc.) did not solve until now our wished and aimed goal to treat patients according to their personal status and setting or specific to their tumor and disease.

Results: Currently, as a responsible health care provider and financier, we face the problem of supporting suboptimal procedures and protocols either at individual or at community level. The problem roots in the overwhelming amount of data and, at the same time, the lack of targeted information for treatment. We expect from the deep learning technology an aid which helps to reinforce and extend the human-human cooperations in patient-doctor visits. We expect that computers take over the tedious work allowing to revive the core of healing medicine: the insightful meeting and discussion between patients and medical experts. 
Conclusion: We should learn the revelational possibilities of deep learning techniques that can help to overcome our recognized finite capacities in data processing and integration. If we, doctors and health care providers or decision makers, are able to abandon our fears and prejudices, then we can utilize this new tool not only in imaging diagnostics but also for daily therapies (e.g., immune therapy). The paper aims to make a great mind to do this.

Keywords: machine learning, artificial intelligence, mammography, user-computer interface

Ribli D, Zsuppán R, Pollner P, Horváth A, Bánsághi Z, Csabai I, Bérczi V, Unger Zs. [Potential applications of deep learning-based technologies in Hungarian mammography]. Orv Hetil. 2019; 160(4): 138-143.

(Beérkezett: 2018. július 26.; elfogadva: 2018. szeptember 10.)

\begin{abstract}
Rövidítések
BI-RADS = (breast imaging-reporting and data system $)$ emlő képalkotó-leletező és adatrendszer; BME = Budapesti Múszaki Egyetem; $\mathrm{CAD}=$ (computer-aided diagnosis) komputeraszszisztált diagnózis; DE = Debreceni Egyetem; ELTE = Eötvös Loránd Tudományegyetem; EU = (European Union) Európai Unió; FDA = (U.S. Food and Drug Administration) az Amerikai Egyesült Államok Élelmiszer-biztonsági és Gyógyszerészeti Hivatala; GPU = (graphics processing unit) videokártyákat hajtó grafikus processzor; ISO $=($ International Organization for Standardization) Nemzetközi Szabványügyi Szervezet; PTE = Pécsi Tudományegyetem; SE = Semmelweis Egyetem; SZTE = Szegedi Tudományegyetem
\end{abstract}

A XXI. század hajnalára számtalan forradalmi újdonság lépett színre a modern orvostudomány igen széles körü palettáján, mindez gyakran észrevétlenül, de mégis rohamléptékben.

A szélesedő ismeretek a betegségek nemcsak komplexebb megértését és gyógyítását tették lehetővé, hanem a háttérben húzódó prediszponáló tényezők, például genetikai és környezeti hatások felismerését is elősegítették. Ezáltal a hagyományos konzervatív medicina egyre inkább az úgynevezett preventív, megelőző szemlélet irányába helyezte fókuszpontját, melynek vezérfonalát a korszerű diagnosztikai módszerek jelentik.

A növekvő ismeretek és tökéletesedő vizsgálómódszerek ellenére, a daganatos megbetegedések a mai napig világszerte számos emberéletet követelnek. A legfrissebb statisztikák szerint a nők körében az emlőrák a leggyakrabban felismerésre kerülő malignus betegség minden megvizsgált populációban és rasszban [1]. Jelentőségét mutatja, hogy a rák okozta halálozásban csupán a tüdőrák előzi meg az emlőtumort [1].

\section{A mammográfia}

A prevenciót előnyben részesítő szemléletváltozásnak köszönhetően az emlőrák gyógyításában és korai diagnózisában kulcsszerepet játszott az 1970-es évek elején kibontakozó radiológiai szubspecialitás, a mammográfia megjelenése. A módszer során az emlők alacsony dózisú, úgynevezett lágy sugárzással végzett kétirányú röntgenfelvétele történik, majd a keletkezett röntgenképeket (mammogram) emlődiagnosztikában jártas radiológus értékeli ki, többek között malignitásra utaló elváltozásokat (például mikromeszesedések) keresve [2].

A kezdeti lelkes törekvéseket szakmai irányelvek, klaszszifikációk (például BI-RADS) kidolgozása követte, így pár évtizeddel az első programok indulását követően az emlőrák elleni harc egyik éllovasává a háttérben dolgozó radiológus és radiológiai személyzet vált. Jelenleg még megoszlanak a vélemények arról, melyik az az életkor, amelyben az első vizsgálatnak meg kell történnie, de elmondható, hogy tünetmentes nők esetében 40 éves kor felett kezdődhet a szürés, éves, vagy kétéves gyakorisággal. Pozitív családi anamnézis, tünetek vagy egyéb magas rizikófaktor esetén természetesen jóval korábban ajánlott a radiológiai vizsgálat, egyes vélemények szerint akár a 30 év alatti korosztály számára is [3].

Ma már a digitális mammográfia bizonyítottan jobb eredményú, mint az analóg filmes technika. A mammográfia az egyetlen, tudományosan igazolt eljárás az átlagos rizikójú nők szűrésére, és a halálozás csökkentésére [4]. A fejlett országokban döntő többségben csak a digitális mammográfiát használják, mind a szürô jellegü (tehát panasz- és tünetmentes pácienseken végzett vizsgálatok), mind a diagnosztikus mammográfia (tüneteket és/vagy panaszokat okozó megbetegedések) esetén [5].

A vizsgálómódszer létjogosultságát nem csupán a 3848\%-os mortalitásiráta-csökkenés mutatja a résztvevők között, hanem az a tény is, hogy döntően az emlőszűrési programoknak köszönhetően, az emlő malignus megbetegedéseinek közel 63\%-ában a diagnózis még az áttétképződések előtt születik meg, az 5 éves túlélési rátát $90 \%$ fölé helyezve $[6,7]$. Természetesen a szürési eredmények csak megfelelő részvételi arány mellett lehetnek hatékonyak, például az előbb említett eredmények eléréséhez minimum 70\%-os megjelenési arány szükséges. Sajnos a hazai tapasztalatok ennél sokkal gyengébb eredményeket mutattak, közel 10\%-os mortalitáscsökkenéssel. A 70\%-os részvételi arány esetére kalkulált várható eredmény hazánkban nem jósolt 30\%-nál magasabb javulást.

Az emlődiagnosztikai protokolloknak megfelelően a szúrésből kiemelt, nem negatív pácienseket tovább kell vizsgálni klinikai komplex emlődiagnosztikai módszerekkel a látott elváltozás tisztázása érdekében. Összességében elmondható, hogy ez a leghatékonyabb eljárás a daganatos betegségek korai diagnózisára [8]. 


\section{Új kihívások}

Noha a felvételi technika ma már széles körben rendelkezésre áll, a vizsgálatok jól reprodukálhatók és könnyen elkészíthető́k, a modern kor új kihívásai további távlatok meghódítására biztatják az emlőszúrésben részt vevő szakembereket.

A fejlett társadalom számára nem új keletû probléma az elöregedés. Mivel az idősebb populációban gyakoribbak a malignus megbetegedések, az elöregedés a beteg populáció növekedésével és az aktív, munkaképes tábor törvényszerú csökkenésével jár, azaz több daganatos megbetegedés szürésével kevesebb szakembernek kell megbirkóznia. A számos kimutatás közül csak egy példát kiragadva: az Egyesült Királyságban 2004-től 2011-ig a képalkotó vizsgálatok mennyisége évenként 26,5\%-kal emelkedett [9]. A nyersvizsgálatok számához hozzájön az új technológiák és az elkészülő felvételek komplexitásának folyamatos bővülése, ami igazán komoly leterheltséget és munkaerőhiányt okoz nemcsak Magyarországon, de a világ valamennyi pontján. Nyilvánvaló, hogy a probléma megoldása új megközelítést igényel, a nehézség áthidalására egy új, még viszonylag gyerekcipőben járó lehetôség, az automatizálás hozhatja el a várva várt megoldást.

Az emlőszürés fejlődése nem csupán a modernebb gépparknak köszönhető. A radiológus egyre magasabb szakmai szintû képzettsége is nélkülözhetetlen. Az új évezred orvosai a számítástechnikai módszereket napi szinten, munkájukba integrálva, alkalmazva, azokkal összhangban dolgozva szárnyalhatják túl korábbi korlátaikat.

A mammográfia mint radiológiai szubspecialitás az egyik legnehezebb és legnagyobb kihívást felvonultató szakág, így a gépi segítség és asszisztálás kérdésköre már korábban is felmerült e szektorban. A vizsgálat a radiológus részéról nagy tapasztalatot, koncentrációképességet igényel, szellemileg megterhelő, és könnyen monotonná válhat, ami végeredményben a diagnosztikus pontosságot rontja, és a hamis pozitív, valamint álnegatív vizsgálatok számának növekedéséhez vezet. E hátrány leküzdésére a szürôvizsgálatoknál széles körben elterjedt az úgynevezett kettős leolvasás technikája, ahol második vélemény is készül a már kiértékelt mammogramról egy független, másik radiológus által. E tevékenységnek köszönhetôen a mammográfiai szưrés specificitása 90-98\%ot, míg szenzitivitása a 83-95\% körüli értéket éri el jelen$\operatorname{leg}[10]$.

\section{Ember és gép együttmúködése}

Az 1980-as évek első felében megjelenő kezdeti próbálkozások az emberi és gépi koprodukcióban (komputerasszisztált diagnózis, CAD) nagy reménységet és hírverést keltett a radiológusok között. Bár számos alkalmazási terület létezik, a CAD alkalmazásának jelentôs részét az emlődiagnosztikai felhasználás teszi ki [11, 12].
A CAD-rendszerek alkalmazása során többlépcsős folyamatról van szó, amelyben számítógépes algoritmusok végeznek képi tulajdonsági analízist és adatfeldolgozást. Az előfeldolgozott képeket mesterséges neuronhálózatokon vagy hasonló gépi intelligenciát alkalmazó eljárásokon végigfuttatva jutnak végül eredményhez [13].

A CAD-technológia fó célja a percepció elősegítése, azaz a számítógépes analízist követően a mammogramon gyanús területek kerülnek bejelölésre, melyek felhívhatják bizonyos elváltozásokra a radiológusok figyelmét, ezáltal pontosítva és könnyítve napi munkájukat. További előny, hogy azokon a helyeken, ahol a munkaerôhiány nem teszi lehetôvé a kettős leolvasást (különösen a leolvasások függetlenségét), ott a gép kiegészítő másodleolvasóként juthat szerephez, de a döntés jogát minden esetben az orvos szakértelmére bízzák.

Ezek a programok orvosi eszközöknek minősülnek, így szigorú törvényi szabályozásoknak kötelesek megfelelni (USA-FDA, EU-ISO13485) [14]. A növekvő igényt is jelzi, hogy a modern mammográfiás készülékekhez e szoftverek egyikét gyakran azonnal meg is vásárolják, és az új készülékek így kerülnek felszerelésre.

Kontrollált körülmények között több tanulmány is kimutatta, hogy egy radiológus CAD segítségével 8-15\%kal több rákos esetet tud detektálni, mint egyedül dolgozva. Többek között egy nagy angol klinikai kutatás szerint az egy orvos - egy szoftver páros nem marad el érzékenységben két független leolvasó teljesítményétől sem [15-17].

Azonban, mint minden modern kezdeményezésnek, a CAD-rendszereknek is megvannak az ellenzőik, akik megoszthatják a véleményeket. Sajnos ezek a kritikák sokszor hiedelmeken, negatív előítéleteken alapulnak.

Az egyik gyakran említett kritika a hamis pozitív diagnózisok állítólagos jelentős növekedése. A legnagyobb kohorszon alapuló elemzések azt mutatják, hogy a CADrendszereket alkalmazó vizsgálatokban ilyen hátrányos tendencia nem jelenik meg [17-19].

A CAD-rendszerekkel szemben emlegetett további kritika, hogy nagy átlagban nem növelik a találati pontosságot. Valóban, a korábbi gépi megoldások hatékonysága az Amerikai Egyesült Államokban (USA) alkalmazott, a gép javaslatait túlzott mértékben felhasználó módszertan szerint hagyott némi kívánnivalót maga után, például a fent idézett retrospektív vizsgálat szerint [18].

Több kontrollvizsgálat és tanulmány eredményeként végül a korábbi, amerikai piacra tervezett $\mathrm{CAD}$-rendszerek magas ára miatt a hagyományos $\mathrm{CAD}$ nem váltotta ki a kettôs leletezés és kettős személyzet igényét az európai szürôprogramok esetében.

Az Európai Radiológus Társaság 2018. évi kongreszszusán (2018. február 28.-március 4.) is a mesterséges intelligencia, ezen belül a deep learning radiológiai vonatkozású alkalmazásaival számos szekció foglalkozott. Az előadók hangsúlyozták, hogy az elmúlt mintegy $\mathbf{5}$ évben történt forradalmi technikai változások alkalmazá- 
sa a radiológiai gyakorlatban is rövidesen elkerülhetetlen lesz.

Az USA-ban azonban, ahol a szoftverfejlesztés és az orvosi személyi költségek eltérnek az európaitól, egy radiológus mellett döntéstámogatói szerepkörben váltak a napi klinikai rutinmunka részeivé [20].

\section{A mélytanulásos (deep learning) módszer}

Az elmúlt 5 évben valódi forradalom zajlott le a számítógépes képfelismerésben. A hagyományos módszerek hibaarányát egy nagyságrenddel csökkentették a mély mesterséges neurális hálózatokon alapuló 'deep learning' rendszerek.

A gépi látás szakemberei által korábban kevéssé preferált módszer számára a milliós nagyságrendű képbőll álló, emberek által annotált adathalmazok és hatalmas számítási kapacitású videokártyákat hajtó grafikus processzorok (GPU) hozták el az áttörést.

A hagyományos képelemző szoftverekben a képet aprólékosan megtervezett, kézzel készített jellemzőkkel próbálták leírni (például elváltozások alakja, mérete), majd egyszerúbb klasszifikációs módszereket alkalmaztak a kinyert jellemzőkön (például szignifikanciavizsgálat, K-közép klaszterezés). A deep learning ezzel szemben a nyersképeket sok egymás utáni szűrősorozattal dolgozza fel, a szưrők paramétereit pedig önállóan, kizárólag az adatokból tanulja. A tanítás iteratív folyamat, amelyben lépésenként néhány felcímkézett képen kell kiértékelni a modellt és minden lépés után olyan irányba változtatni a paramétereket, hogy egyre kevesebbet hibázzon a gép.

A deep learning előretörését jellemzi, hogy a mindennapi képeket tartalmazó legnagyobb referencia-adathalmazon a legjobb deep learning alapú módszerek már csak 2,2\% hibát ejtenek, míg a hagyományos megközelítések 25\%-ot hibáznak [21], azaz ilyen mértékben sikerült csökkenteni a tévesen pozitívnak vagy tévesen negatívnak jelölt képfelvételek számát. A deep learning ma már az életünk része, a telefonok a rajtuk készített képeket deep learning segítségével elemzik és rendszerezik. Valószínúleg eljött az ideje, hogy az orvosi gyakorlatban is leváltsa a deep learning a hagyományos képelemző módszereket.

Ezt ismerte fel a DREAM challenges csoport, amikor meghirdette a digitálismammográfia-elemzési versenyt, The Digital Mammography DREAM Challenge néven. A versenyt az előző amerikai kormány által kihirdetett Cancer Moonshot projekt keretében szervezték és finanszírozták. A kihívás során nagyjából százezer mammográfiás felvételt kellett elemezni a versenyzőknek, és megjósolni, hogy az adott vizsgálat után 1 éven belül mellrákkal diagnosztizálták-e a szưrés résztvevőjét vagy sem. A versenyben 1200 résztvevő közül egy fiatal magyar résztvevő, e cikk első szerzője szerezte meg a második helyezést. A módszer leírása szabad hozzáférésú tudományos publikációként a közelmúltban jelent meg a Nature Scientific Reportsban [22].

Az eljárás legfontosabb lépéseit az 1 . ábra szemlélteti, amelyen egy digitális mammográfiai kép feldolgozási út-

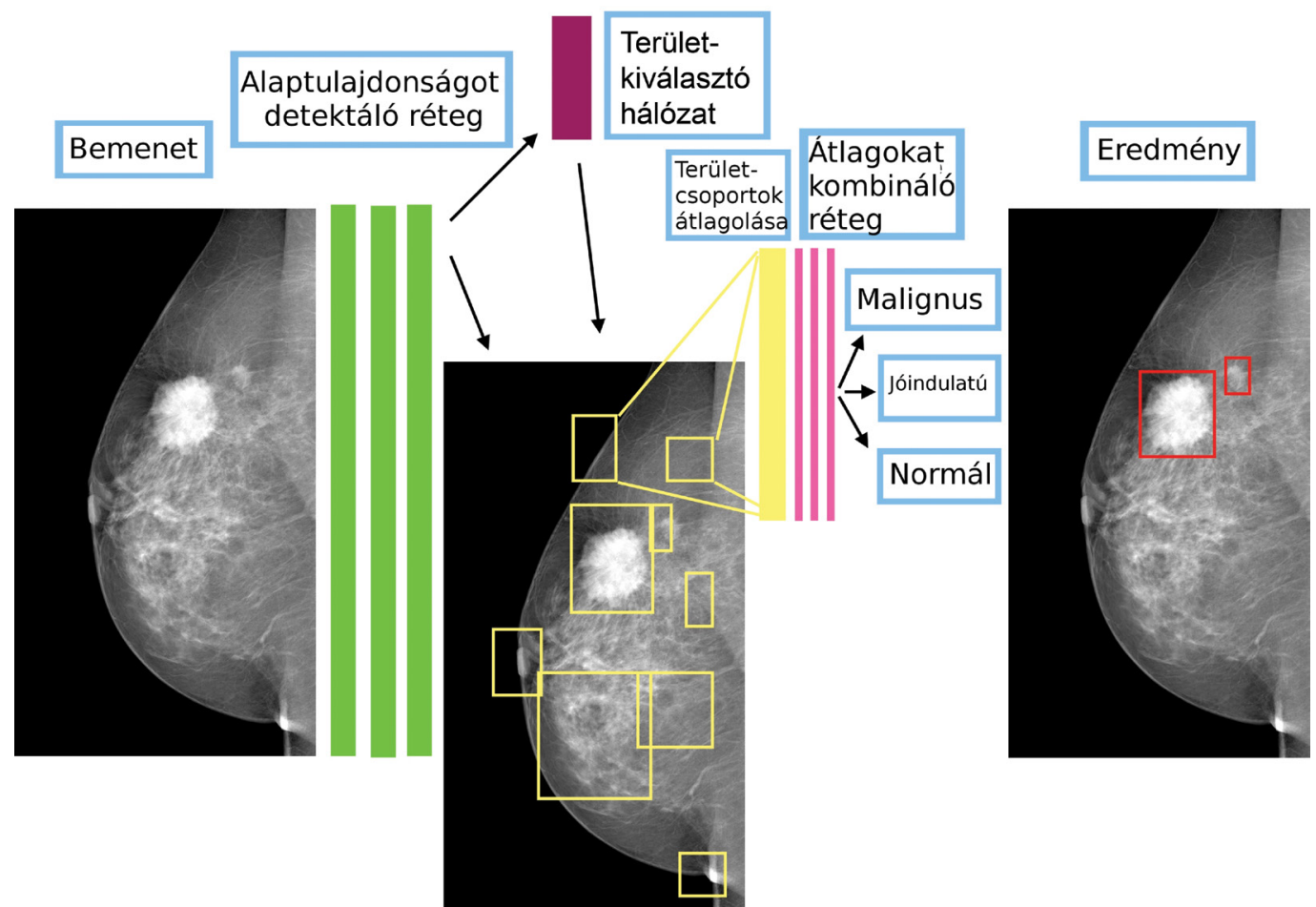
\begin{tabular}{l|l} 
1. ábra & $\begin{array}{l}\text { Egy mammogram mélytanulásos feldolgozási lépései. A bemeneti képen nincsenek jelölések. A feldolgozás során a szoftver megjelöl különböző tar- } \\
\text { tományokat különféle képi sajátságok alapján (téglalapok a középső ábrán), például a háttér és az emlő határa, erős kontrasztkülönbségek stb. A jobb }\end{array}$
\end{tabular} szélső képen már csak a malignus jellemzőkkel rendelkező tartományokat tartja meg 
vonalát követhetjük végig. A módszer alapját egy úgynevezett konvolúciós hálózat adja, amelyet néhány további, magasabb szintû, aggregáló és szűrő neurális hálózati réteg egészít ki. A konvolúciós neurális hálózatokat speciálisan képek feldolgozására fejlesztették ki. A konvolúciós neuron a sima mesterséges neuronhoz hasonlóan súlyozottan összegzi a bemeneti jeleket egy kimeneti jellé. Ezt az összegzést úgy végzi, hogy egy preferált bemeneti mintázatra legyen a legérzékenyebb, azaz szürőként múködjön. A konvolúciós neuron abban különleges, hogy a bemeneti kép minden pozíciójában ugyanannak a neuronnak egy másolata értékeli ki a kép adott részét, ugyanazokkal a súlyokkal. Ennek a tulajdonságnak köszönhetóen a konvolúciós neurális hálózatok a képek legfontosabb tulajdonságát, az eltolásinvarianciát, azaz a detektált objektumok pozíciófüggetlenségét tudják nagyon hatékonyan figyelembe venni.

A mammográfiai elemzést végző neurális hálózat tanításához több, publikusan elérhető paraméterhalmazt kellett felhasználni annak érdekében, hogy a képeken található elemi szintû objektumokat detektálni lehessen: például a kontúrokat, a vonalakat, az árnyalatokat stb. Néhány ezer mintakép felhasználásával pedig a magasabb szintû rétegeket lehetett megtanítani, amelyek elemi objektumok kombinációjával eredményesen meg tudták találni a rosszindulatú elváltozásokat.

A képelemző konvolúciós neurális hálózat múködését a legegyszerúbben úgy képzelhetjük el, mintha lenne egy nagyon gyors és nagyon szorgalmas asszisztensünk, aki papírlapokba több, különböző méretû́ és alakú lyukat vágott. Ezeket a lapokat egymás után ráfektetve a mammogramra, csak a lyukon át látható tartományra koncentrálva, minden részletet megvizsgál, amikor végighúzza a lapot a kép minden pontja felett. Azokat a tartományokat, amelyek olyan képi objektumokat tartalmaztak olyan arányban, mint amilyeneket rosszindulatú daganat esetén már korábban látott a tanítóhalmazokban, megcímkézi egy gyanússági pontértékkel. Az így nyert, leggyanúsabb képrészletek helyeit ezután bejelöli az eredeti képen egy-egy téglalappal. Az alkalmazás során csak a rosszindulatú tumorok jelöléseit mutatja.

A módszer teljesítőképességét többféleképpen is lehet jellemezni. A mindennapok számára a legbeszédesebb mérőszámok a szenzitivitás (a rosszindulatú tumorok közül hány százalékot talál meg) és a tévesen bejelölt területek száma (hamis pozitívok száma). A gép gyakorlatilag szinte minden egyes képrészletre mond egy tumorvalószínúségi mutatót, és ezekből a képekből kell kiválasztani a szenzitivitásnak megfelelő számú találatot. $\mathrm{Az}$ algoritmus akkor lesz hasznos a gyakorlatban, ha csak néhány téves jelölés mellett a valódi malignus helyek magas hányadát megtalálja. A szenzitivitás értékét tehát 0-tól 100\%-ig tetszőleges értékre be lehet állítani, a döntő kérdés, hogy mennyi hamis pozitív jóslata lesz.

A mélytanuló rendszer által javasolt (jelölt) helyek számáról, a várható hibás jelölések arányáról fontosnak tartjuk megjegyezni a következőt. A szoftver alkalmazása során először be kell állítani egy adott érzékenységi szintet. Az érzékenység rögzített értéke mellett a hibás, azaz hamis pozitív jelölések átlagos száma független lesz az összjelölések, a helyes jelölések számától. Extrém példaként, ha egy képsorozaton képenként 100 malignus terület látható (a mammográfiai gyakorlatban ilyen nagy szám nem szokott előfordulni), az algoritmus akkor is megtartja az érzékenységi szintnek megfelelő képenkénti hibás átlagot, azaz a jelölések számához viszonyítva nagyon kis tévesztési arányt fog mutatni. De a képenkénti átlagos hibás jelölések számát akkor is megtartja, ha csupa egészséges képet elemeztetünk. A képenkénti átlagos hamis pozitív jelölések méröszámát a legpontosabban egy kizárólag negatív képeket tartalmazó halmazon lehet lemérni.

A bemutatott szoftver a nemzetközi publikáció beküldésének időpontjában képes volt megtalálni a rosszindulatú tumorok 90\%-át úgy, hogy 10 képre átlagosan csak 3 darab téves jelölést rakott. Ha pedig azt követeltük meg, hogy bármi áron jelölje be az összes rákos elváltozást, akkor is csupán 2-4 téves jelölést rakott átlagosan egy-egy képre. A diagnosztizáló orvos szakmai döntéshozó szerepe a CAD-rendszerek esetén tehát nem egyszerúen a gép által javasolt területek rutinjellegú felülvizsgálata, hanem az algoritmus érzékenységének tudatos beállítása és a kapott javaslatok értékelése a beállított érzékenységi szint figyelembevétele mellett.

\section{Következtetés}

Egy akadémiai kutatás vagy egy verseny eredménye akkor válik igazán értékessé, ha a mindennapokban is használható alkalmazás készül belőle. Egy megfelelő technológiai újítás a korai rák felfedezési arányait növelheti.

Ehhez járulhat hozzá az a formálódó hazai együttmüködés, amely a számítógépes szoftverek és algoritmusok fejlesztőit közvetlenül összekapcsolja a napi gyakorlat problémáival szembesülő és a gyógyítás iránt elkötelezett radiológiai központokkal.

Amennyiben a módszer a számos soron következő tesztelés során is sikerrel bizonyít, úgy megoldhatóvá válhat a mammográfiai szúrés olyan kórházakban, ahol a szakemberek jelentősen túl vannak terhelve, és az intézmény erőforráshiánnyal küzd. A felszabadított kapacitásnak hála a radiológusoknak és az egészségügyi személyzetnek több ideje, valamint lehetősége marad kutatási területeken vagy egyes szubspecialitásokban való komplexebb elmélyülésre, a napi és monotonabb rutinjellegű munkát átengedve a gépi asszisztenciának.

Ezért is kulcsfontosságú, hogy a jelen és jövőbeli szakemberek megértsék e módszerek fontosságát és megtanulják napi használatát, bennük ne ellenséget vagy vetélytársat lássanak, hanem partnert, amellyel az együtt való munka által, közös erővel többet érhetnek el a betegek gyógyítása érdekében.

Nagyon fontos, hogy a hazai környezetben is nagyobb léptékben folytatódjon a mesterséges intelligencia orvosi 
alkalmazása. Ez részben már zajlik is, például hazai jelentôs pályázatok beadása is történt ilyen vonatkozásban. Az a cél, hogy itthon is konkrétan alkalmazható termékek szülessenek. Ezekhez a folyamatokhoz elengedhetetlen, hogy az orvostanhallgatók is ismerkedjenek ezekkel a témákkal. A Semmelweis Egyetemen már 2018 szeptemberétől szabadon választott tantárgy keretében oktatják a mesterséges intelligencia orvosi vonatkozásait. A technikaibb jellegú szempontok oktatását több egyetem is tervezi (SE, ELTE, BME, DE, SZTE, PTE) a hamarosan induló bioinformatikusképzések keretében.

Anyagi támogatás: A mélytanuló rendszer fejlesztése részben a FIEK_16-1-2016-0005 sz., „Molekuláris biomarker kutatási és szolgáltatási központ” kialakítása az ipari igények kiszolgálása érdekében címú projekt keretében, a Nemzeti Kutatási Fejlesztési és Innovációs Alapból biztosított támogatással, a FIEK_16 pályázati program finanszírozásában valósul meg.

Szerzői munkamegosztás: R. D., P. P., Cs. I.: A technológiai koncepció kidolgozása és megfogalmazása. U. Zs., H. A.: Az adatok értelmezése, elemzése. Zs. R., U. Zs., H. A., B. Z., B. V.: Az orvosi koncepció és az alkalmazási szempontok megfogalmazása. A cikk végleges változatát valamennyi szerző elolvasta és jóváhagyta.

Érdekeltségek: A szerzőknek nincsenek érdekeltségeik, amelyek hatással lehetnek a cikk tartalmára.

\section{Irodalom}

[1] CDC - Cancer data and statistics. Available from: http://www. cdc.gov/cancer/dcpc/data/women.htm [accessed: July 1, 2018].

[2] Screening Mammography - Inside Radiology. Available from: http://www.insideradiology.com.au/screening-mammography [accessed: July 1, 2018].

[3] Forrai G, Ambrózay É, Bidlek M, et al. Use of imaging methods in the current screening, diagnostics and treatment of breast cancer - Professional guidelines. 3rd Breast Cancer Consensus Meeting. [A képalkotó vizsgálómódszerek alkalmazása az emlődaganatok korszerú szúrésében, diagnosztikájában és ellátásában - Szakmai útmutató a III. Emlőrák Konszenzus Konferencia alapján.] Magy Onkol. 2016; 60: 181-193. [Hungarian]

[4] Tabar L, Yen MF, Vitak B, et al. Mammography service screening and mortality in breast cancer patients: 20-year follow-up before and after introduction of screening. Lancet 2003; 361: Pl405-P1410.

[5] Smith RA, Cokkinides V, Brooks D, et al. Cancer screening in the United States, 2011: a review of current American Cancer Society guidelines and issues in cancer screening. CA Cancer J Clin. 2011; 61: 8-30.

[6] Broeders M, Moss S, Nyström L, et al. The impact of mammographic screening on breast cancer mortality in Europe: a review of observational studies. J Med Screen. 2012; 19 (1_Suppl): $14-25$.

[7] Breast Cancer Survival Rates \& Statistics. Available from: http:// www.cancer.org/cancer/breast-cancer/understanding-a-breastcancer-diagnosis/breast-cancer-survival-rates.html [accessed: July 1,2018$]$.

[8] Mayo Clinic. Breast Cancer. Available from: http://www.mayoclinic.org/diseases-conditions/breast-cancer/diagnosis-treatment/drc-20352475 [accessed: July 1, 2018].

[9] The Royal College of Radiologists. Available from: http://www. rcr.ac.uk/sites/default/files/RCR_CRWorkforce_June2012. pdf [accessed: July 1, 2018].

[10] Institute of Medicine (US) and National Research Council (US) Committee on New Approaches to Early Detection and Diagnosis of Breast Cancer; Joy JE, Penhoet EE, et al. (eds.) Saving women's lives: strategies for improving breast cancer detection and diagnosis. National Academies Press, Washington DC, 2005.

[11] Harvey D. Navigating through the data - CAD applications in liver, prostate, breast, and lung cancer. Radiol Today 2010; 11 : 18.

[12] Rao VM, Levin DC, Parker L. How widely is computer-aided detection used in screening and diagnostic mammography? J Am Coll Radiol. 2010; 7: 802-805.

[13] Dheeba J, Albert Singh N, Tamil Selvi S. Computer-aided detection of breast cancer on mammograms: a swarm intelligence optimized wavelet neural network approach. J Biomed Inform. 2014; 49: 45-52.

[14] EN ISO 13485:2016 Medical devices - Quality management systems - Requirements for regulatory purposes. Available from: https://standards.cen.eu/dyn/www/f?p=204:110:0::::FSP_PR OJECT:37957\&cs=1B04E3A6EA841FF02235DCA86690F76 5D [accessed: July 1, 2018].

[15] Birdwell RL, Ikeda DM, O'Shaughnessy KF, et al. Mammographic characteristics of 115 missed cancers later detected with screening mammography and the potential utility of computeraided detection. Radiology 2001; 219: 192-202.

[16] Brem RF, Baum J, Lechner M, et al. Improvement in sensitivity of screening mammography with computer-aided detection: a multiinstitutional trial. Am J Roentgenol. 2003; 181: 687-693.

[17] Gilbert FJ, Astley SM, Gillan MG, et al. Single reading with computer-aided detection for screening mammography. N Engl J Med. 2008; 359: 1675-1684.

[18] Lehman CD, Wellman RD, Buist DS, et al. Diagnostic accuracy of digital screening mammography with and without computeraided detection. JAMA Intern Med. 2015; 175: 1828-1837.

[19] Fazal MI, Patel ME, Tye J, et al. The past, present and future role of artificial intelligence in imaging. Eur J Radiol. 2018; 105: 246-250.

[20] Castellino RA. Computer aided detection (CAD): an overview. Cancer Imaging 2005; 5: 17-19.

[21] He K, Zhang X, Ren S, et al. Delving deep into rectifiers: surpassing human-level performance on ImageNet classification. In: Proceedings of the 2015 IEEE International Conference on Computer Vision, 2015; pp. 1026-1034.

[22] Ribli D, Horváth A, Unger Zs, et al. Detecting and classifying lesions in mammograms with deep learning. Sci Rep. 2018; 8: 4165 .

(Pollner Péter dr., Budapest, Pázmány P. sétány 1/A, 1117 e-mail: pollner@angel.elte.hu)

A cikk a Creative Commons Attribution 4.0 International License (https://creativecommons.org/licenses/by/4.0/) feltételei szerint publikált Open Access közlemény, melynek szellemében a cikk bármilyen médiumban szabadon felhasználható, megosztható és újraközölhető, feltéve, hogy az eredeti szerző és a közlés helye, illetve a CC License linkje és az esetlegesen végrehajtott módosítások feltüntetésre kerülnek. (SID_1) 